\title{
Improvement of Creative Thinking Ability of Elementary Teacher Education Students in Utilizing Traditional Games in Social Studies Learning
}

\author{
Hana Sakura Putu Arga ${ }^{{ }_{1}}$, Faridillah Fahmi Nurfurqon ${ }^{2}$, Riga Zahara Nurani ${ }^{3}$ \\ 1,2 Primary Teacher Education Program, IKIP Siliwangi, Cimahi, Indonesia \\ 3 Primary Teacher Education Program, Universitas Perjuangan, Tasikmalaya, Indonesia \\ $\triangle$ hana-sakura@ikipsiliwangi.ac.id
}

\begin{abstract}
Creative thinking skills of elementary teacher education students' needs to be improved in a fun social studies learning process. One of the lessons that can make learning a pleasant atmosphere is to apply knowledge by applying traditional games. This research aims to increase the creativity of elementary teacher education students in utilizing traditional games to preserve the nation's culture. The research method used was a quasi-experimental design with a nonrandomized pretest-posttest control group. The instrument used in this study was a tablet-shaped observation instrument. This research shows that learning science by applying traditional games can improve elementary teacher education students' creative thinking skills. It can be seen from the learning outcomes of elementary teacher education students social studies using traditional games that are better than conventional learning.
\end{abstract}

Keywords: creative thinking skills, social studies learning, traditional game media

How to Cite: Arga, H., Nurfurqon, F., \& Nurani, R. (2020). Improvement of Creative Thinking Ability of Elementary Teacher Education Students in Utilizing Traditional Games in Social Studies Learning. Mimbar Sekolah Dasar, 7(2), 235-250. doi:https://doi.org/10.17509/mimbar-sd.v7i2.26347.

INTRODUCTION Indonesia has many traditional children's games, which is one form of Indonesia's wealth. There are 800 more traditional children's games spread across the archipelago (Lestariningrum, 2018). In ancient times, traditional games were prevalent among the people. Traditional games are not only games that are played but also have cultural values that can be taken. But over time, the entry of foreign cultures into one's own culture has created a cultural crisis for its own culture. With access to foreign cultures, it is realized that this will shift people's interest in their regional culture and even affect traditional arts preservation in each region (Sulistyaningtyas \& Fauziah, 2019). The phenomenon of changing children's play activities today is different from 20 or 30 years ago. Children often play modern games synonymous with technology, such as video games and online games on smartphones. As a result, traditional children's games have begun to be forgotten and become foreign among children. Besides, the level of addiction to modern games is also high, affecting children's habits and behavior (Lestariningrum, 2018). Children who are addicted to playing with gadgets are less interested in playing in open spaces. It is caused because children often see judged every day and are not interested in physical interactions, resulting in children's thinking ability. These problems must be addressed immediately, and of course, social studies have an essential role in resolving these problems. In the field activities, students need to implement a learning 
Hana Sakura Putu Arga et al. Improvement of Creative Thinking Ability...

process that enhances cognitive abilities and affective and psychomotor, providing space for students to have good social skills (Marhadi, 2018). To achieve this, the use of instructional media can influence students' social skills to interact socially well, one of which is to implement social studies based on traditional game media.

Traditional games improve children's motor movements that can stimulate muscle and brain growth for the better. Muscles and the brain can work in balance so that by itself able to encourage increased intelligence in thinking children. Also, traditional games can increase social interactions that affect children's communication skills, mutual respect, and sportsmanship through the rules in the game to control emotions and empathy between others (Suherman et al., 2019). Through traditional games, children learn to love nature more and increase spiritual values to God through moral attitudes and values. Nature provides valuable lessons so that children are always grateful for all the gifts given by God through abundant natural wealth. Children are also required to be more creative and imaginative in solving their play problems (Aribowo \& Hidayah, 2019).

The aim of social studies in elementary school is so that students understand their potential and adapt to their environment. Elementary school education is the process of developing children to build themselves. They can be responsible for national development, continuing education to the next level, live in the community, and set themselves according to their talents, interests, abilities, and environment (Aris Rahmadani et al., 2018). Teachers teach students social attitudes to introduce students' basic competencies and social attitudes to apply to the community environment. Students who have social attitudes have honest, forgiving, helpful themes, polite to parents, can respect the teacher (Sofiasyari et al., 2020).

The main objective of social studies learning is to foster student attitudes to be sensitive to social problems in society. Education has an essential role in human life. The education process in Indonesia must be able to enrich knowledge, realize potential, and empower students so that their character is more developed as citizens (Sofiasyari et al., 2020). At the same time, traditional games are a treat or practice to develop social attitudes through games (Kovačević \& Opić, 2014). Therefore learning social studies and traditional games have the same goal of developing children's social skills. This traditional game-based learning model is fundamental to making social studies learning more useful and more enjoyable in the learning process. Students need environmental changes to carry out enjoyable learning processes (Abu-hamdan \& Khader, 2014). Social science is a branch of science that has never been separated from us since we were born and will never end to be studied. Social studies learning is a very close science to our daily and formal life, both formally and informally. We will always learn it. In other words, Social studies have an integrated perspective with all subjects (Daulay, 2018). Social studies learning emphasizes education and debriefing of students. The emphasis 
is limited to mere concepts but lies in their efforts to make what we have learned into values that develop in our lives and society's environment (Temli et al., 2011).

In social studies learning the ability to solve problems is needed in the learning process. In contrast, the ability to solve problems requires women to think Christianically. The ability to think critically in social studies is expected to use women to think critically to face the life context (Huang et al., 2017). Social studies aim to prepare students as citizens who master knowledge, skills, attitudes, and values that can be used to solve personal or social problems and make decisions and participate in various community activities (Nugraha et al., 2018).

The ability to think creatively is a crucial factor in influencing the learning process. On the one hand, teachers need to have sufficient knowledge about creativity to develop student creativity in the right way. One alternative learning that can improve the ability to think creatively is learning that gives students space to find and build their concepts and develop thinking skills (Suswandari et al., 2020). The creative thinking idea in this study can be seen from the form of ratio function, which is interpreted as a process. That is, that activity is a process of thinking to find answers to a problem using new ways to know new relationships between symptoms, facts, and concepts in social studies learning (Tatli, 2018).

The ability to think creatively is the ability to think of someone looking at several perspectives, both the old perspective and the new perspective, to create different ideas based on solving a problem (Suryadi, D., \& Herman, 2008). Someone who can think highly creative will be able to create innovations in life, including education. Sometimes things that are considered in the past can be new and different if it is in the hands of someone who can think creatively. According to Trajkovik et al. (2018), a person needs to understand, master, and solve their problems in different ways by thinking creatively. It's just that the general public is still low in innovation to produce new creations, sometimes when there are new ideas that are considered other ideas that are not inline (Yunianta. T.N.H., A. Rusilowati, 2012).

Social studies learning will be very optimal when learning using teaching media. Still, learning media has advantages and disadvantages, which can arouse student learning motivation, clarify the information provided to students, and make use of variations in the learning process (Asmahasanah et al., 2018). Traditional games are one of the media that can be applied in the learning process and gives the impression of pleasant learning for students, especially elementary school students. According to Akbari et al. (2009), traditional games for children provide educational values that can foster and develop nine children's intelligence. Intelligence that can be developed is linguistic, mathematical, visual-spatial, musical, kinesthetic, naturalist, interpersonal, and spiritual. It is using learning strategies while playing, centered on children and meaningfulness. To implement learning by utilizing the traditional game, the educator must improve their ability to think creatively. In this study, researchers 
Hana Sakura Putu Arga et al. Improvement of Creative Thinking Ability...

coordinate with the elementary teacher education program lecture to immediately solve these educational problems. One of the efforts made is to apply learning with traditional game media in the learning process to rebuild the values of national character in elementary teacher education students. Therefore, this study is focused on improving the creative thinking skills of prospective elementary school educators in creating fun social science learning.

\section{LITERATURE REVIEW}

The ability to think creatively is something someone needs to solve problems (Larasati et al., 2018). Someone will be more independent and able to solve various issues within him/her by thinking creatively (Astuti et al., 2020). Creative thinking skills also encourage a person to innovate to create an idea that will change for the better (Rugiero, 1998). In creating innovation to develop creative thinking skills, of course, good collaboration and communication are needed to achieve an expected goal (Suwardana, 2018).

Traditional games are one of the nation's cultures that are starting to be forgotten by the young generation (Rahayu et al., 2018; Mardayani et al., 2016; Risdiyanti \& Prahmana, 2018). Traditional games contain fun elements in their activities and have national cultural values that can shape a person's character (Noviza \& Kassim, 2018; Rahmat et al., 2018; Suherman et al., 2019; Tatli, 2018). The traditional game is one solution that can be used to make the learning process fun. It's just that the ability to think creatively for educators is needed to apply traditional games in the learning process by determining learning themes, the material to be taught, and suitability with traditional games that can be used to achieve goals expected. Therefore, prospective elementary school educators must improve their creative thinking skills to create traditional game-based learning media to introduce the national culture and provide learning meaning for students (Huang et al., 2017; Kettler, 2014; Sriningsih Haning, 2018).

Social science lessons focused on ordering individuals who can understand social life can carry out activities and activities in their social environment. They are formed to become responsible citizens, have broad ideas, and think in the long term for present and future life (Asmahasanah et al., 2018). It is necessary to have learning that provides direct experience in the learning process to provide real and life experiences to achieve science goals. NCSS (1997) states that an excellent educational curriculum is a curriculum that can combine personal, academic, and global pluralism. Social study is a solution informing individuals who have knowledge in social values, behavioral skills, and knowledge that can be applied in life because social studies provide information about the relationship between humans and their environment (Agung, 2018). 


\section{METHOD}

The research methodology used in this study is quasi-experimental. According to Sugiyono (2012), the quasi-experiment research method is research used to determine whether something is imposed on the subject under investigation by looking for the effect of specific treatments on others under controlled conditions. It is understood that quasi-experiments see how researchers' actions impact whether the experiment will affect the research subjects.

\section{Research Design}

The research design used was a nonrandomized pretest-posttest control group design. The research subjects were divided into two groups consisting of the experimental group and the control group. Here is a quasi-experimental research design, according to Sugiyono (2013):

Tabel 1. Research Design Non-Randomized pretest-posttest control group design

\begin{tabular}{llcl}
\hline \hline Class & Pre-test & Treatment & Post-test \\
\hline \hline Experiment & $\mathrm{O}$ & $\mathrm{X}_{1}$ & $\mathrm{O}$ \\
\hline Control & $\mathrm{O}$ & $\mathrm{X}_{2}$ & $\mathrm{O}$ \\
\hline \hline
\end{tabular}

Information:

$\mathrm{O}=$ Pretest-posttest decision-making skills

$\mathrm{X}_{1}=$ Learning by applying traditional game media

$\mathrm{X}_{2}=$ Conventional learning

The steps of the research activities carried out in this study are as follows:

1. Formulating the problem and developing an assessment of elementary teacher education students' creative thinking ability in utilizing traditional games as a learning media

2. Determining two research classes, namely the experimental class, and the control class

3. Providing a general description of the subject of research regarding research activities to be carried out

4. Reflecting and discussing the activities carried out in teaching

5. Collaborating with other lecturers in determining the experimental class and the control class

6. Implementing pre-test for experiment and control classes

7. Implementing learning activities by applying social studies learning by utilizing traditional games as social studies learning media

8. Evaluating learning activities in social studies learning by applying traditional game media in the form of post-tests and interviews with students

9. Drawing conclusions from the results of the analysis and data processing obtained in this study 
Hana Sakura Putu Arga et al. Improvement of Creative Thinking Ability...

10. Making teaching material in the form of learning videos and social studies learning steps by utilizing traditional games as social studies learning media

\section{Participants}

Participants in this study were students of fifth-semester prospective elementary education teachers. The total number of participants was 50 students. Participants for the experimental class totaled 25 students, consisting of six male students and 19 female students. The control group consisted of 25 students, including five males and 20 females. The age range for all participants was 19-21 years. The researcher chose a sample of two groups of fifth-semester students. Groups one and two were randomly selected in determining the control class and the experimental class. The two groups were given a pre-test and post-test with the same questions. The reason the fifth-semester students were chosen was with the assumption that the fifth-semester students were able to adapt to various kinds of learning models, especially learning models that made use of traditional games.

\section{Instruments and Data Analysis Technique}

The research data in quantitative data were obtained from the pre-test and post-test results using the observation sheet. The following is an explanation of the analysis and management of quantitative data from students' written tests. The pre-test and post-test answer scores are calculated based on the answer key, and the scores are converted into values with the following formula:

$$
\mathrm{N}=\frac{\text { total score obtained }}{\text { maximum number of scores }} X 100
$$

\section{RESULTS}

Here is an explanation of the research results on increasing elementary teacher education students' creative thinking ability in utilizing traditional games in the experimental class. The results showed a significant increase in elementary teacher education students' creative thinking ability in experimental class students. The results of this study were obtained through data processing and analysis using the SPSS application. The results of management are as follows.

\section{Normality Test}

The pre-test and post-test normality test of creative thinking aim to find out whether the test has a normal distribution or not. Testing the normality of the pre-test and post-test scores of creative thinking utilizing the traditional game was carried out by the Kolmogorov-Smirnov normality test. 
SPSS 22 application at significance level $a=0.05$ or $5 \%$. Hypothesis test for the normality of the distribution of pre-test and post-test score data The ability to think critically using traditional gameplay in the experimental class and the classroom control console is as follows:

Ho: pre-test and post-test scores have a normal distribution

$\mathrm{H1}$ : pre-test and post-test scores are not normal. The test criteria using SPSS 22 software are based on significance level $a=5 \%$.

$\mathrm{H}_{0}$ : accepted if the significance value $\geq 0.05$

$\mathrm{H}_{0}$ : rejected if the significance value $<0.05$

Based on calculations using SPSS, the process of calculating normality test data in detail can be presented via the table below.

Table 2. Normality Test

\begin{tabular}{|c|c|c|c|c|c|}
\hline \multirow[t]{2}{*}{ Class } & & \multicolumn{2}{|c|}{ Kolmogorov-Smirnov } & \multirow[t]{2}{*}{ Conclusion } & \multirow[t]{2}{*}{ Information } \\
\hline & & Statistic & Sig. & & \\
\hline \multirow[t]{2}{*}{ Pre-test } & Experiment & 0.141 & 0.132 & Horeceived & Normal \\
\hline & Control & 0.159 & 0.051 & $\mathrm{H}_{0}$ received & Normal \\
\hline \multirow[t]{2}{*}{ Post-test } & Experiment & 0.154 & 0.068 & Horeceived & Normal \\
\hline & Control & 0.131 & 0.199 & $\mathrm{H}_{0}$ received & Normal \\
\hline
\end{tabular}

Based on calculations using the Kolmogorov-Smirnov normality test. The experimental class's pre-test creative thinking is 0.132 , which means it is more significant than $a=0.05$. It is shown that the experimental class is normally distributed. The control class pre-test results, which results in 0.051 , show that the control class is normally distributed, meaning that the hypothesis is accepted. The sample comes from a population that is normally distributed.

From Table 2, the Kolmogorov-Smirnov normality test shows that the post-test results of the experimental class's learning motivation are 0.068. Meanwhile, the control class is 0.199 , which means that both classes have a significance value greater than a $=0.05$ or $5 \%$. It is shown that the control class and the experimental class are normally distributed, which means the two samples are accepted. The sample comes from a population that is normally distributed.

\section{Homogeneity Test}

The homogeneity test is done when the similarity test of two variances is used to test whether the data distribution is homogeneous or not by comparing the two variances. A homogeneity test can be done if the data group is in a normal distribution. Based on the normality test results of creative thinking using traditional games from the pre-test and post-test values of the experimental class and the control class, which normally distributed, then the homogeneity test was performed. 
Hana Sakura Putu Arga et al. Improvement of Creative Thinking Ability...

The homogeneity test was carried out using the SPSS 22 application through the Homogeneity of Variances (Levene Statistics) test with a significance level of $a=0.05$ or $5 \%$. The hypothesis proposed is as follows:

$\mathrm{H}_{0}$ : the variance score of the experimental class and homogeneous control class $\mathrm{H}_{1}$ : the variance score of the experimental class and the control class is not homogeneous Test criteria if sig. based on mean $\geq 0.05$, then $\mathrm{HO}$ is accepted, and $\mathrm{H} 1$ is rejected. If sig. based on mean $<0.05$, then $\mathrm{HO}$ is rejected, and $\mathrm{Hl}$ is accepted. The following are the results of the pretest and post-test test for the homogeneity of learning motivation.

Tabel 3. Homogeneity Test

\begin{tabular}{lcccl}
\hline \multirow{2}{*}{ Class } & \multicolumn{2}{c}{ Homogeneity } & Information & Conclusion \\
\cline { 2 - 3 } & Levenne Statistic & Significance & & \\
\hline Pre-test & 1.583 & 0.213 & Horeceived & Homogen \\
\hline Post-test & 0.404 & 0.528 & Horeceived & Homogen \\
\hline
\end{tabular}

Table 3 shows that the Homogeneity of Variances (Levene Statistic) test results of creative thinking utilizing the traditional game of the pre-test and post-test results of the control class and the experimental class have a significant value than $a=0.05$ is 0.213 for the pre-test. Meanwhile, 0.528 for the post-test means both data have a homogeneous variance.

\section{Test the Difference between Pre-test and Post-test Score}

Test differences in the average pre-test and post-test scores were conducted to prove no significant difference between the experimental class's initial ability and the control class.

The following are the hypothesized pairs of each variable tested by the student ( $t$ ) and student $(t)$ tests. The pair of motivational learning hypotheses are presented as follows:

$\mathrm{H}_{0}$ : there is no difference in creative thinking between the experimental class and the control class

$\mathrm{H}_{1}$ : there are differences in the ability to think creatively between the experimental class and the control class and class

Criteria for acceptance of the statistical hypothesis:

$H_{0}=\mu_{1}=\mu_{2} \quad$ (the average experimental class is the same as the average control class)

$H_{1}=\mu_{1} \neq \mu_{2} \quad$ (the average experimental class is not the same as the average control class)

Testing criteria:

If the significance (2-tailed) $\geq \mathrm{a}=0.05, \mathrm{HO}$ is accepted, and $\mathrm{H} 1$ is rejected. If the significance (2-tailed) $<\mathrm{a}=0.05, \mathrm{HO}$ is rejected, and $\mathrm{H} 1$ is accepted. Calculation of the average similarity 
test of pre-test and post-tests using the SPSS 22 application. Following are the results of the test calculation - † Compare Mean Independent Sample Test.

Tabel 4. Test Results Difference in Average Pre-test and Post-test Scores

\begin{tabular}{|c|c|c|c|c|c|}
\hline $\begin{array}{l}\text { Class } \\
\text { information }\end{array}$ & & & $T$ & Sig.(2-tailed) & conclusion \\
\hline \multirow[b]{2}{*}{ Pre-test } & Experiment & \multirow[b]{2}{*}{-0.630} & \multirow[b]{2}{*}{0.531} & \multirow[b]{2}{*}{$\mathrm{H}_{0}$ received } & \multirow[b]{2}{*}{ No difference } \\
\hline & Control & & & & \\
\hline \multirow[b]{2}{*}{ Post-test } & Experiment & \multirow[b]{2}{*}{6.632} & \multirow[b]{2}{*}{0.000} & \multirow[b]{2}{*}{$\mathrm{H}_{0}$ received } & \multirow[b]{2}{*}{ difference } \\
\hline & Control & & & & \\
\hline
\end{tabular}

Based on Table 4, the pre-test results did not show any difference in the average value of the initial ability between the experimental class students and the control class students because of $\mathrm{HO}$ received. While in the post-test results, there are differences in creative thinking utilizing traditional games between the experimental and control classes.

\section{Improved Analysis}

The N-Gain calculation of creative thinking in the control class has an average pre-test score of 34.23, and after the post-test, there is a slight increase to 35.14 and are classified in the low category level. N-Gain creative thinking experiment class obtained an average value of 33,599, and after the post-test, there was an increase so that the average motivation score was 43,084. N-gain's average value indicates an increase in learning motivation by 0.37 , categorized in the medium category. From the two N-Gain averages, it can be seen that there are differences in the improvement of students' creative thinking in the control class and the experimental class.

\section{Classroom Learning}

Learning in the experimental class was carried out in class. A class of 2018 elementary teacher education students utilized traditional games as teaching material in elementary teaching and learning strategies courses. Students are divided into groups in the learning process and given the task to make teaching materials using traditional games as a learning resource. Students make observations and use traditional games in each group, such as observing other groups, making traditional games to be applied to students when learning outside the classroom, and present teaching materials by utilizing the traditional game in front of the class. The character values reflected in the traditional game values in the traditional game are the values of discipline, responsibility, agility, social, health, cooperation, harmony, and creativity. A group must awaken students' critical and reasoning power through various teaching variations (Rahmat et al., 2018). Therefore, this traditional game can be used as a starting point or context in making learning designs for elementary school children (Prahmana et al., 2012). 
Hana Sakura Putu Arga et al. Improvement of Creative Thinking Ability...

Indonesia is known to have a rich cultural diversity. The culture is the wealth of the Indonesian people that must be preserved. Local cultural values are found in various cultural phenomena in the community. One of them is in the traditional children's game. Traditional games have their meaning in instilling attitudes, behavior, and skills in children. There are sublime meanings contained therein, such as religious values, educational values, norms, and ethics, whose findings will be useful in future social life (Kun \& Nayan, 2019). Traditional games are an activity carried out by children in physical development and mental attitude in question. These physical activities can be done merely as leisure time and to solve daily life fatigue or intended to foster daily life skills and attitudes in broader social relations (Dewi et al., 2018). Play is a tool that allows children to develop; indirectly, playing can affect children's development to learn about themselves, family, peers, and the environment around children (Çengelci, 2013).

\section{Control Class Learning}

Control class learning is carried out in the class B class of the 2018 elementary teacher education student in elementary teaching and learning strategies. The process of learning money conducted in the control class is conventional learning that uses the group presentation method using power points and making papers on the use of traditional games as primary school teaching materials. In the learning process, several findings were found-first, the lack of students' readiness to deliver material about the use of traditional games. Second, the lack of exciting power points that were made and made other students pay less attention to the percentage when the group presentation took place. According to Marlina (2017), an educator needs to foster and develop students' attention in the learning process. It is recommended that attention in following the learning process should arise based on these students' high awareness to learn. Furthermore, teachers are expected to provide motivation and guidance to students, and the goal is that students have a higher desire to learn so that attention in learning will get better.

The problem that often arises in formal education (schools) is the low absorption of students. It is evident from the average results of research, which are always very alarming. In this case, students cannot understand how to learn, think, and motivate themselves. Though these aspects are the key to success in learning, this problem is often found in teaching and learning activities in the classroom. Thus, it is necessary to apply an appropriate learning model that can increase students' interest in learning, develop students' minds and reasoning, and develop the ability to convey information that they know by oral and written (Kettler, 2014).

\section{DISCUSSION}

\section{Learning in the Experimental Class}


In the experimental class, learning is done by applying traditional games in social studies learning. The research was conducted at the campus majoring in elementary teacher education students for students in class 2018. The implementation of learning was carried out during two meetings. At the first meeting, the experimental class students were directed to apply social studies learning through traditional games such as the Sodor, Enggrang, Long Dragon, Galah, Benteng-Bentengan, Boy-Boyan, etc. (Rosita et al., 2020). In the implementation, students are assigned to adjust elementary school teaching materials with traditional games and make lesson plans and simulations to implement traditional social studies learning games. There are several things found in the learning process where students are still less conducive to learning implementation because it is not usual to apply traditional games. But the lecturer gives more direction and guidance so that students are accustomed to and understand the learning.

In the second lesson, students were more mature in making research plans, as seen from the accuracy in choosing traditional games with the material to be delivered. When students carry out simulations, students are more flexible, and learning is conducive. Other students who become audiences are enthusiastic about enjoying fun learning. Thus, applying traditional games in social studies can improve students' ability to think creatively in implementing fun learning in choosing the right methods, media, and learning models. The application of traditional games can preserve the nation's culture through games with learning value, especially in social skills (Utsman et al., 2018).

From the two learning meetings in the experimental class, it can be concluded that the second learning is quite good as explained in the results section that social studies learning in traditional games can increase the eco-literacy of elementary school students.

\section{Learning in the Control Class}

Learning conducted in the control class was given to students of the elementary teacher education 2018 class, held in two meetings by applying conventional learning. The conventional learning activities carried out in the first meeting were the learning activities carried out, as usual, namely the material exposure activities given by the lecturer and the question and answer discussion about the elementary social studies learning material, which was simply discussed. In the implementation of the first learning activity, there are findings: students look bored in paying attention to lecturers' explanations when delivering material seen from students' behavior, such as sleepy, some are chatting and not paying attention. In the question and answer activity, only a small proportion of students were willing to express their opinions, and the majority were silent. 
Hana Sakura Putu Arga et al. Improvement of Creative Thinking Ability...

In the second study, the study's preparation was more mature to anticipate things at the first meeting. The learning activities also used a different method, namely, by doing group presentations. The implementation of student learning becomes more active and creative in presenting learning materials in power points. The audience also seems enthusiastic in question and answer activities. Students who provide material can convey well and make learning media interesting. Students who listen to explanations are more vigorous in paying attention and expressing their opinions. The improvement results in the second learning show a positive effect that is seen to be an increase in students' creative thinking ability compared to the pretest results.

Based on the results of the discussion in this study, it is hoped that this research can provide implications such as, 1) learning by applying traditional games in social studies learning can improve creative thinking skills in prospective elementary school educators, 2) learning with traditional games can improve the social skills of elementary teacher education student and can be instilled in learning when later starting to teach, 3) learning with traditional games in preserving national culture in the form of games that have cultural values and characters, 4) learning by applying traditional games can create a pleasant learning atmosphere.

\section{CONCLUSION}

Based on the results and findings of the research conducted and explained earlier, it can be concluded that 1) learning by applying traditional games in social studies learning can improve the creative thinking ability of elementary teacher education students; 2) social studies learning in traditional games is better than conventional learning; 3) learning requires careful learning planning to produce the maximum quality of learning and can provide opportunities for students to make teaching materials by utilizing traditional games in social studies learning.

\section{RECOMMENDATIONS}

It is expected that with the implementation of this research, students' prospective elementary school teachers can develop this research in greater depth by innovating implementing learning by preserving the nation's culture through traditional games. Indonesia has a unique diversity and contains character values, one of which is a traditional game. Innovations that prospective educators can make are creating traditional games that can be applied in the social studies learning process to make it more meaningful and enjoyable. The steps that can be taken in using traditional games in social studies learning are:

Students adjust elementary school social studies learning materials and design games that can be applied in the learning process to increase student creativity in innovation.

1. Students plan preparations carefully so that the performance when teaching is maximized

2. Students are given guidance on how the traditional game work that is made 
3. Students carry out social studies learning by applying traditional game models in groups and explaining how the game is carried out. Other students who do not presentations pay attention to their friends who are presenting the material

4. Students follow the learning and conduct Q\&A sessions.

5. Students and lecturers conclude the learning conducted and give an impression of the learning that has been carried out.

It is hoped that with this study, there will be other research that can develop traditional games in social studies learning so that learning is more fun and meaningful.

\section{ACKNOWLEDGMENTS}

Thank you to the Directorate General of Strengthening Research and Development of the Ministry of Research, Technology, and Higher Education. They have provided research funding through the budding lecturer research program to be carried out smoothly according to targets and objectives.

\section{REFERENCES}

Abu-hamdan, T., \& Khader, F. (2014). Social Studies Teachers' Perceptions of Teaching Contemporary Controversial Issues. American Internasional Journal Of Contemporary Reserch, 4(10), 70-78.

Agung, L. (2018). Character Education Integration in Social Studies Learning. Historia: Jurnal Pendidik Dan Peneliti Sejarah, 12 (2), 392. https://doi.org/10.17509/historia.v12i2.1211 1

Akbari, H., Abdoli, B., Shafizadeh, M., Khalaji, H., Hajihosseini, S., \& Ziaee, V. (2009). The effect of traditional games in fundamental motor skill development in 7-9 year-old boys. Iranian Journal of Pediatrics, 19(2), 123-129.

Aribowo, D. S., \& Hidayah, T. (2019). The Effectiveness of Indonesian Traditional Games and Agility on Student's Gross Motor Skills in Elementary School Hj. Isriati Baiturrahman 2 Semarang. Journal of Physical Education and Sports, 8(3), 281-287.

Aris Rahmadani, N. K., Latiana, L., \& AEN, R. A. (2018). The Influence of Traditional Games on The Development of Children's Basic Motor Skills. Advances in Social Science, Education and Humanities Research (ASSEHR), 169(Icece 2017), 160-163. https://doi.org/10.2991/icece-17.2018.41

Asmahasanah, S., Ibdalsyah, I., \& Sa'diyah, M. (2018). Social Studies Education in Elementary Schools Through Contextual REACT-Based on Environment and Sociopreneur. International Journal of Multicultural and Multireligious Understanding, 5(6), 52. https://doi.org/10.18415/ijmmu.v5i6.487

Astuti, A., Waluya, S. B., \& Asikin, M. (2020). The Important of Creative Thinking Ability in Elementary School Students for 4.0 Era. International Journal of Educational Management and Innovation, 1 (1), 91. https://doi.org/10.12928/ijemi.v1i1.1512 
Hana Sakura Putu Arga et al. Improvement of Creative Thinking Ability...

Çengelci, T. (2013). Social studies teachers' views on learning outside the classroom. Kuram ve Uygulamada Egitim Bilimleri, 13(3), 1836-1841. https://doi.org/10.12738/estp.2013.3.1410

Daulay, M. I. (2018). Developing Social Science-History's Comics- Based Learning Media for the Fifth Grade of Primary School In Pekanbaru City. International Journal of Research in Counseling and Education, 1 (1), 15. https://doi.org/10.24036/008za0002

Dewi, N. L. M. A., Suryati, Y., Rudhiati, F., \& Mediani, H. S. (2018). The Effect of Traditional Game of Magoak-Goakan to The Prosocial Behavior among Preschool Children (5-6 Years Old) At Maria Fatima Kindergarten Jembrana Bali. IOSR Journal of Nursing and Health Science, 7(5), 1-7. https://doi.org/10.9790/1959-0705020107

Huang, M. Y., TU, H. Y., Wang, W. Y., Chen, J. F., YU, Y. T., \& Chou, C. C. (2017). Effects of cooperative learning and concept mapping intervention on critical thinking and basketball skills in elementary school. Thinking Skills and Creativity, 23(101), 207-216. https://doi.org/10.1016/j.tsc.2017.01.002

Kettler, T. (2014). Critical Thinking Skills Among Elementary School Students: Comparing Identified Gifted and General Education Student Performance. Gifted Child Quarterly, 58(2), 127-136. https://doi.org/10.1177/0016986214522508

Kovačević, T., \& Opić, S. (2014). Contribution of traditional games to the quality of students' relations and frequency of students' socialization in primary education. Croatian Journal of Education, 16(Spec. Edition 1), 95-112.

Kun, O. H., \& Nayan, S. M. (2019). Jom Main! (Let's Play!): Promoting The Values Of Malaysia Traditional Children's Games Through The Media. Media Literacy and Academic Research, 2(2), 52-84.

Larasati, N., Santosa, S., \& Sari, D. P. (2018). The Influence of Cooperative Learning Model of Group Investigation Type Combined Concept Map to Student's Creative Thinking S. Proceeding Biology Education Conference, 15(2528-5742), 130-137.

Lavega, P., Sáez-de-Ocáriz, U., Lagardera, F., March-Llanes, J., \& Puig, N. (2017). Emotional experience in individual and cooperative traditional games. A gender perspective. Anales de Psicología, 33(3), 538. https://doi.org/10.6018/analesps.33.3.260811

Lestariningrum, A. (2018). The Effects Of Traditional Game 'Congklak' And Self-Confidence Towards Logical Mathematical Intelligence Of 5-6 Years Children. Scientific Journal of Preschool and Early School Education, III(I), 13-22. https://doi.org/https://doi.org/10.24269/jin.v3n1.2018.pp13-22

Mardayani et al. (2016). Penerapan Permainan Tradisional Engklek Untuk Meningkatkan Kemampuan Motorik Kasar Kelompok B Di PAUD Widhya Laksmi (Application of Traditional Engklek Games to Improve Gross Motor Skills for Group B in PAUD Widhya Laksmi). Journal Pendidikan Anak Usia Dini, 4(2), 1-10.

Marhadi, H. (2018). Implementation of Social Care Character Valve in Social Studies in Primary School. Proceedings of the UR International Conference on Educational Sciences, 0(0), 
$546-550$.

Marlina, S. (2017). Character Values Development in Early Childhood through Traditional CHARACTER VALUES IN EARLY The Concept of Character The Principles of Character Values Development from the Early Age. Advances in Social Science, Education and Humanities Research (ASSEHR) International Conference on Early Childhood Education, 58, 404-408. https://doi.org/https://doi.org/10.2991/icece-16.2017.71

NCSS. (1997). Expectations of Excellence: Curriculum Standards for Social Studies. Library of Congress.

Noviza, N., \& Kassim, A. H. B. M. (2018). Traditional Game Model of South Sumatra Malay Muslim Community in Reducing the Tendency of Children to Play "Skip Challengge." 19(1), 1-18. jurnal.radenfatah.ac.id/index/article/view/2433

Nugraha, Y. A., Handoyo, E., \& Sulistyorini, S. (2018). Traditional Game on The Social Skill of Students in The Social Science Learning of Elementary School. Journal of Primary Education, $7(2)$, 220-227. https://doi.org/https://journal.unnes.ac.id/sju/index.php/jpe/article/view/23475 Traditional

Prahmana, R. C. I., Zulkardi, \& Hartono, Y. (2012). Learning Multiplication Using Indonesian Traditional game in Third Grade. 3(c), 2-6. https://doi.org/https://doi.org/10.22342/jme.3.2.1931.115-132

Rahayu, D., Hamid, S. I., \& Sutini, A. (2018). Improving Early Childhood Social Skills Through Traditional Games. Jurnal Dimensi Pendidikan Dan Pembelajaran, 7(2), 1-8. https://doi.org/10.17509/cd.v7i2.10527

Rahmat, R. F., Fahrani, O. R., Purnamawati, S., \& Pasha, M. F. (2018). The development of indonesian traditional bekel game in android platform. Journal of Physics: Conference Series, 978(1). https://doi.org/10.1088/1742-6596/978/1/012009

Risdiyanti, I., \& Prahmana, R. C. I. (2018). Ethnomatematics: Exploration in Javanese Traditional Games. Journal of Medives : Journal of Mathematics Education IKIP Veteran Semarang, 2(1), 1. https://doi.org/10.31331/medives.v2i1.562

Rosita, T., Nurhayati, S., Jumiatin, D., Rosmiati, A., \& Abdu, W. J. (2020). Using traditional roleplay games by adults to nurture a culture of cooperation among children amidst widespread engagement in online games within today's technological society. Journal of Critical Reviews, 7(7), 183-186. https://doi.org/10.31838/jcr.07.07.29

Sofiasyari, I., Atmaja, H. T., \& Suhandini, P. (2020). The Implementation of Character Education on the Thematics Learning for the Fourth Graders of Primary Schools. Journal of Educational Social Studies, 16-23. https://doi.org/http://journal.unnes.ac.id/sju/index.php/jess The

Sriningsih Haning, K. B. J. R. S. H. (2018). Improving Students' Creative Thinking Ability Through Application Of Demonstration Learning Methods In The Points Of Changes In Objectives. 
Hana Sakura Putu Arga et al. Improvement of Creative Thinking Ability...

Creative of Learning Students Elementary Education, 01 (06), 315-326.

Sugiyono. (2012). Metode Penelitian Kuantitatif Kualitatif dan R\&D (Qualitative and Quantitative Research Methods R \& D). Alfabeta.

Sugiyono. (2013). Metodelogi Penelitian Kuantitatif, Kualitatif Dan R\&D (Quantitative, Qualitative and R \& D Research Methodologies). Alfabeta.

Suherman, W. S., Dapan, Guntur, \& Muktiani, N. R. (2019). Development of traditional children play based instructional model to optimize development of kindergarteners' fundamental motor skill. Cakrawala Pendidikan, 38(2), 356-365. https://doi.org/10.21831/cp.v38i2.25289 Sulistyaningtyas, R. E., \& Fauziah, P. Y. (2019). The Implementation of Traditional Games for Early Childhood Education. July, 5-10. https://doi.org/10.2991/iccie-18.2019.75

Suryadi, D., \& Herman, T. (2008). Eksplorasi Matematika Pembelajaran Pemecahan Masalah (Exploration of Mathematical Problem Solving Learning). Karya Duta Wahana.

Suswandari, M., Siswandari, Sunardi, \& Gunarhadi. (2020). Social skills for primary school students: Needs analysis to implement the scientific approach based curriculum. Journal of Social Studies Education Research, 11(1), 153-162. https://doi.org/10.13140/RG.2.2.24413.77288

Tatli, Z. (2018). Traditional and Digital Game Preferences of Children: A CHAID Anal1. Nur'ani F. Edu Games for Child. 2008; ysis on Middle School Students. Contemporary Educational Technology, 9(1), 105. https://doi.org/https://doi.org/10.30935/cedtech/6213

Temli, Y., Sen, D., \& Akar, H. (2011). A Study on Primary Classroom and Social Studies Teachers' Perceptions of Moral Education and Their Development and Learning. Educational Sciences: Theory and Practice, 11(4), 2061-2067. http://ezproxy.umsl.edu/login?url=http://search.ebscohost.com/login.aspx?direct=true\& $\mathrm{db}=$ eric \&AN=EJ962688\&site=ehost-live\&scope=site

Trajkovik, V., Malinovski, T., Vasileva-Stojanovska, T., \& Vasileva, M. (2018). Traditional games in elementary school: Relationships of student's personality traits, motivation and experience with learning outcomes. PLOS ONE, 13(8), 1-15. https://doi.org/10.1371/journal.pone.0202172

Utsman, A. F., Ni'mah, R., \& Rohana, R. (2018). Peran Permainan Tradisional dalam Meningkatkan Motorik Kasar Anak Usia 5-6 Di RA Al Fattah Pacing Parengan Tuban (The Role of Traditional Games in Improving Gross Motoric of Children Ages 5-6 at RA Al Fattah Pacing Parengan Tuban). Al Ulya : Jurnal Pendidikan Islam, 3(2), 132-141. https://doi.org/10.36840/ulya.v3i2.156

Yunianta. T.N.H., A. Rusilowati, R. (2012). Kemampuan Berpikir Kreatif Siswa Pada Implementasi Project-Based Learning Dengan Peer and Self-Assessment (Students' Creative Thinking Ability in Implementing Project-Based Learning with Peer and Self-Assessment). Unnes Journal of Research Mathematics Education, 1(2), 81-86. https://doi.org/http://journal.unnes.ac.id/sju/index.php/ujmer. 